\title{
Perceptions on the Use of Movies and Multimodal Aspects for Teaching Conversational Competence to Porter Students
}

\author{
Arief Eko Priyo Atmojo \\ arief.atmojo93@iain-surakarta.ac.id \\ IAIN Surakarta
}

\begin{abstract}
This study addresses these following questions: (1) How are the students' and teachers' perceptions toward the use of movies to teach conversational competence to porter students in a vocational high school?; (2) How are the students' and teachers' perceptions toward the use of movies to facilitate the students' understanding of verbal and non-verbal conversational competence in the target situation of the job they will encounter as porters?; and (3) How can multimodal aspects help the students to master the conversational competence needed to become porters as reflected on the movies used in this study? This study employs descriptive qualitative design. The results show that movies are perceived to improve the conversational competence of porter students in a vocational high school. Movies facilitate the students' understanding of verbal and non-verbal conversational competence in the target situation of the job they will encounter as a porter. The multimodal aspects help the students to master the conversational competence needed to be a porter as reflected on the movies. Therefore, movies along with their multimodal aspects are worthy for teaching conversational competence to porter students.
\end{abstract}

Keywords: conversational competence, movies, multimodal aspects, porter students.

\section{INTRODUCTION}

The connection between listening and speaking is intertwined in a very special relationship. According to Brown (2004), there is an intention to mix some skills to allow English language learners to perform better in communicative competence. Osada (2004) argues that speaking cannot stand alone in communication but it must be comprehensible to listen. In addition, Bozorgian (2012) states that developing listening skill generates significant improvement in other skills. However, students' lack of motivation becomes a major problem (Celik \& Yavuz, 2015).

In oral communication, we need to express utterances fluently and appropriately because it is believed as the significant goal of language instruction. However, teaching speaking skill is put behind other skills, such as reading, writing, and listening. The biggest challenge nowadays is to find effective ways for teaching the students to be able to communicate spontaneously. Thus, conversational competence has become important for the students.

Teaching conversational competence to vocational high school students, in this case porter students, mainly concentrates on output processing and fluency through oral communicative activities. According to Oprandy (1994), communication is achieved through two-way system, namely listening and speaking. Conversational competence can be achieved through authentic 
input. However, the exposure to authentic input and the availability of authentic materials have often been missing.

One thing that has also been missing from the teaching of conversational competence is contexts which are rarely built by teachers. Byrne (1986) states that the more the students know about oral communication from cognitive, socio-cultural, and semiotic perspective, the more the students can have comprehension on oral communication. It can be done by giving them a proper context of the conversation such as the knowledge about who the participants are, where the conversation takes place, the topic they talk about, and how language is used for. The idea of context in listening and speaking has been widely discussed by experts. For instance, Brown \& Yule (1983) argue that comprehension can only occur if listeners put a context.

It is supported by some studies conducted by experts such as Brown (1998) who states about the importance of context in teaching language. Previously, he states that schemata and context are significant for understanding language use. In addition, Garrod (1986) argues that the focus is not the literal meaning but the mental representation which is provided by contextual information. Thus, it is clear that language is not only about linguistic system but also linguistic elements in concrete settings and situations.

Another problem in teaching conversational competence to hotel management students in vocational high schools is the lack of authentic materials used by teachers to embody the attributes of oral communication. According to Jaén \& Basanta (2009), the common practice of English Language Teaching (ELT) still lacks of promoting samples using real conversational features. The practice is based on textbook conversations using scripted dialogues which are mostly drawn from written language depicting someone's intuition about what people want to say. It is because the teachers may be not aware that texts can become multimodal by employing visual and verbal modes (Goodman, 1996).

Nowadays, teachers are required to use multimedia materials such as movies to create cultural authentic contexts. Multimedia materials such as movies are better to develop the real context or situation than the pages of a textbook (Kramsch \& Anderson, 1999). It is because language is not only about lexical items and grammatical paradigm, but it is also about verbal and non-verbal behaviors along with the contexts in which words are uttered. According to Jaén \& Basanta (2009), there are many benefits of using movies as follows: (1) Movies can be controlled; (2) Movies are authentic materials; (3) Movies provide multimodal aspects; (4) Movies promote real vocabulary acquisitions; (5) Movies make teaching more attractive; (6) Movies promote students' active involvement; and (7) Movies foster students' oral production.

This study is beneficial as it can give the teachers insights about the use of movies to facilitate the students' learning. The use of movies creates students' schemata and context on what utterances which are used by porters, how they express those utterances, how they behave in front of guests, the tone of voices used to speak to their guests which reflects politeness, and other verbal and non-verbal conversational competencies. It makes the students to learn conversational competence by knowing the real context or situation in their future job and workplace through the use of authentic materials namely movies.

The research questions of this study are therefore formulated as follows: (1) How are the students' and teachers' perceptions toward the use of movies to teach conversational competence to porter students in a vocational high school?; (2) How are the students' and teachers' perceptions toward the use of movies to facilitate the students' understanding of verbal and non-verbal conversational competence in the target situation of the job they will encounter as porters?; and 
(3) How can multimodal aspects help the students to master the conversational competence needed to become porters as reflected on the movies used in this study?

\section{METHOD}

This study employed qualitative approach. Sukmadinata (2012) defines qualitative approach as the approach of study which aims at describing and analyzing phenomena, events, social activities, attitudes, beliefs, perceptions, and thoughts of individual person or group. Moreover, the design used in this study was descriptive study. According to Kothari (2004), descriptive study is a research design which describes the characteristics of a specific individual or group. It aims at portraying the characteristics of a specific individual, situation, or group accurately.

This study took place in a private vocational high school located in Ngawi, East Java, Indonesia. The participants of this study were 20 students of grade $X$ and 2 teachers (an English teacher and a hotel teacher). The sampling technique used in this study was purposive sampling because the sample was selected for a particular purpose (Alston \& Bowles, 2003). The participants were requested to give responses on a close-ended questionnaire. As a follow-up, ten students and two teachers were invited for an individual semi-structured interview. Participant observation was also done to the students. To ensure the data validity, methodological triangulation was employed. The data were then analyzed using qualitative data analysis developed by Miles, Huberman, \& Saldaña (2014). They perceive analysis as three concurrent flows of activities: (1) data condensation, (2) data display, and (3) conclusion drawing/verification.

\section{FINDINGS AND DISCUSSIONS}

Teaching activities were done by utilizing movies combined with discovery learning. According to Schunk (2008), discovery learning is defined as a method of constructing and testing hypothesis. It means that the students obtain knowledge by themselves. Kirschner, Sweller, \& Clark (2006) argue that this method can be related to problem-based, inquiry, experiential, or constructivist learning. Students find information and knowledge through observations. It includes inductive reasoning because it moves from a specific topic to formulating rules and principles.

The movies entitled Mr. Bean in Room 426, Monte Carlo, The Tourists, and The Impossible were played in some meetings. These movies were selected because there were many scenes of porters in these movies. The students were allowed to watch the movies in advance without interruption in the middle of the movies. It was done to make the students find information and knowledge from the movies by themselves. When each movie finished, the students were given some questions related to the multimodal aspects and conversational competence of porters such as costumes, gestures, and intonations to check whether the students obtained new knowledge or not.

Students' and teachers' perceptions on the use of movies were investigated by utilizing an observation checklist and a questionnaire. The results of observation checklist and questionnaire can be seen below.

Table 1

The Results of Observation Checklist

\begin{tabular}{clc}
\hline No. & \multicolumn{1}{c}{ Objects of Observation } & Score \\
\hline 1 & Students' motivation in learning English & 8 \\
\hline 2 & Students' interest in English & 8 \\
\hline 3 & Joyful learning in the classroom & 9 \\
\hline 4 & Students' participation in the classroom & 7 \\
\hline
\end{tabular}




\begin{tabular}{lll}
\hline 5 & Students' understanding of verbal conversational competence & 8 \\
\hline 6 & Students' overview on the real job situation & 9 \\
\hline 7 & Students' understanding of non-verbal conversational competence & 8 \\
\hline
\end{tabular}

Besides, twenty students and two teachers were requested to give responses on a close-ended questionnaire. The students' and the teachers' perceptions on the use of movies for teaching conversational competence were shown through the results of questionnaire in the form of percentage on each item or statement.

Table 2

The Results of Questionnaire

\begin{tabular}{|c|c|c|}
\hline No. & Statements & Percentage \\
\hline 1 & The use of movies can improve the students' motivation to learn English. & 81.44 \\
\hline 2 & The use of movies can increase the students' interest in English. & 79.55 \\
\hline 3 & The use of movies can make the teaching and learning of English enjoyable. & 84.47 \\
\hline 4 & The use of movies can increase the students' active participation in the classroom activities. & 75 \\
\hline 5 & $\begin{array}{l}\text { The use of movies can help the students to understand verbal conversational competence in } \\
\text { the target situation. }\end{array}$ & 78.79 \\
\hline 6 & The use of movies can provide the overview of target situation to the students. & 80.3 \\
\hline \multirow[t]{2}{*}{7} & $\begin{array}{l}\text { The use of movies can help the students to understand non-verbal conversational } \\
\text { competence in the target situation. }\end{array}$ & 81.06 \\
\hline & Average & 80.09 \\
\hline
\end{tabular}

Having presented the results of observation and questionnaire in the forms of quantitative data, the results obtained from interview are reported in the form of qualitative data.

\section{The Use of Movies to Teach Conversational Competence}

From the observation checklist, it is found that the students' motivation in learning English is high. It indicates that both of the teachers perceive that the students are well-motivated to learn English. It can be seen from their observable behaviors. When the movies were played, the students focused their attention on the movies. Most of them watched the movies seriously. They made some notes when the porter explained about the hotel facilities as shown in The Tourist movie. The results of questionnaire also show that the use of movies can improve the students' motivation to learn English as much as $81.44 \%$.

The students had the same perceptions that the use of movies could motivate them to learn English. By watching movies, they knew that English is an international language mostly spoken by people over the world. Meanwhile, a porter is the first person who welcomes the guests by using the international language. So, English is really important for people who work in a hotel, such as a porter.

Another fact revealed is that the students became interested in English as much as $79.55 \%$ since they got exposure of the use of English from the movies. Student F and student J stated that the situation in the classroom was really interesting and exciting. They said that they were never so enthusiastic to answer the teacher's questions before. They realized that the use of movies played an important role in the lesson. Furthermore, student I argued that the use of movies could avoid stress since she could get both knowledge and entertainment at the same time.

Each actor in the movies speaks English well. Student $\mathrm{H}$ explained that he was interested in listening to what the actors said in the movies. He argued that the pronunciation of the natives was really accurate. The actors' pronunciation allowed him to imitate the accurate pronunciation. Moreover, the English teacher stated that the students could listen carefully to the pronunciation 
of the native speakers. The movies allowed the students to imitate the pronunciation and intonation which are better taught through the use of movies. The teacher also perceived that the conversational competence of the students was improved through the use of movies with integrated steps namely listening then speaking.

As stated previously, conversational competence can be achieved through authentic input. Through the use of movies, the students did two-way system activity in the classroom. They did not only watch visually the situation where the conversation occurred on the movies but also listened to the utterances spoken by the actors. By listening to the utterances, the students were able to speak by using correct pronunciation, appropriate vocabularies, and suitable context related to the porter's jobs.

Another discovered finding is that the use of movies can make the teaching and learning of English enjoyable as much as $84.47 \%$. The situation of teaching and learning in the classroom was really joyful. When Mr. Bean in Room 426 movie was played, all the students laughed and enjoyed the movie. They felt as if they did not study in formal situation. They also did not realize when the lesson was over so they had to stop the movie. Moreover, the students said that they were bored to join the lesson if it was textbook oriented. They easily got sleepy when the teacher only gave explanation based on the textbook. On the contrary, the use of movies was very attractive for the students. It enhanced the students' motivation and interest and created joyful learning situation.

The use of movies can also increase the students' active participation in the classroom activities as much as $75 \%$ because the students enjoyed the classroom activity first. They were eager to participate in the question and answer session. Many students wanted to seek some different movies to learn individually at home. The teachers also perceived that the lesson became alive when the movies were employed. They argued that movies are worthy to use as multimedia materials.

To sum up, the students' and teachers' perceptions toward the use of movies to teach conversational competence to porter students in a vocational high school is that the movies are very useful to teach the conversational competence. The students were able to understand the topic of conversation, the setting, the context, and the situation. The use of movies can improve the students' motivation to learn English and increase their interest in English. It also makes the teaching and learning of English enjoyable. As results, the students' active participation in the classroom activities increases.

\section{How Movies Facilitate the Students to Understand Verbal and Non-Verbal Conversational Competence}

Some facts related to the students' understanding of verbal and non-verbal conversational competence were obtained. The results of observation and interview indicate that the students understood the verbal conversational competence of a porter. When the students were given some questions in the end of the movies such as "What did the porter say to ask permission to carry the baggage?", they were not afraid to express their opinions. Their answers were varied, started from "Excuse me, could I ...." to "How could I assist you, Mam?".

When the students were given questions on some visual aspects of the porter such as "What did the porter wear?", most of them raised their hands to answer the question. They recognized that the porter usually wears a vest or suit, a shirt, trousers, a tie, and shoes. To check the students' answers, the movie was then replayed back and paused in several scenes to show the students that their answers were right or wrong. The movies can flexibly be replayed back and forward, paused, or slowed down to achieve the instructional goals. Ultimately, the students were able to identify 
the porter's uniform. In the end of the lesson, the students had an overview on the real situation of their future jobs. They knew it from the setting of the hotel displayed in the movies.

In general, the use of movies is perceived to provide the overview of target situation to the students as much as $80.3 \%$. Moreover, the use of movies is believed to help the students to understand verbal conversational competence in the target situation as much as $78.79 \%$. It is also noticed that the use of movies also helps the students to understand non-verbal conversational competence in the target situation as much as $81.06 \%$.

Related to the overview of the real situation of the job, all the students agreed that the movies allowed them to have an overview of their office in the future. Many students could explain the job-tasks of a porter after watching the movies. They explained that a porter usually helps the guests by carrying their luggage like in The Impossible movie, advising on the hotel facilities as shown in The Tourists movie, or giving directions to the guests. Student $\mathrm{G}$ stated that she could know the real situation of the hotel by only watching the movies. She explained that she had never gone to a hotel yet, but she could imagine it. Moreover, the hotel accommodation teacher argued that the movies could be excellent media to give the students the overview of their future job. The English teacher added that the use of movies became the best solution to facilitate the students to know verbal and non-verbal conversational competence used in the target situation of the job.

According to the students' and teachers' perceptions, it is clearly stated that movies are the best media to teach verbal and non-verbal conversational competence in the target situation of the job that the students will encounter as porters. Movies provide the real activities occurring in a hotel. It means that movies are authentic materials which help the students to understand the conversational competence of the target language in the target situation of a specific job, namely a porter. Indeed, movies can represent real-life situation and language.

\section{Useful Multimodal Aspects to Master Conversational Competence}

The multimodal aspects on the movies help the students to understand the conversational competence. Student A mentioned that the uniform of a porter includes a vest or suit, a shirt, trousers, a tie, and shoes. The porter usually looks neat and confident. Student B added that most of the porters shown in the movies are men. Student $\mathrm{C}$ then argued that porters are usually men since they are responsible to carry the guests' luggage which is better done by men.

Student D stated that porters have to look neatly since the porters are the person who work in front desk and welcome the guests at the first time. It is important for the porters to do so to increase the guests' satisfaction. Student E argued that the porters always smile because it is important to be friendly with the guests. She added that the porters had to ask permission first to the guests if they wanted to carry the guests' luggage. She learned it from Mr. Bean in Room 426 movie. In the movie, the guest would be angry if the porter did not ask permission.

Student $F$ pointed out that he was able to recognize the porter's gesture when asking for tips. She explained that the porter would never say to the guest directly if he wanted to get some money. The porter usually raises his right hand up to the waist to show that he needs tips. Student G added that a porter would cough if the guest did not understand what he wanted. Moreover, student $\mathbf{J}$ noticed that if the guest did not want to give the tips to the porter, the porter would not be angry. The porter had to keep smile and went back to the front desk.

Student $\mathrm{H}$ recognized another multimodal aspect namely linguistic. He noticed that verbal utterances used by the porter are always in the second form of modal auxiliary such as would and could. It happened since the porter wanted to show his politeness to the guests. Student I added that the porter always uses low intonation when speaking and never shouts to the guests. These 
results indicate that multimodal aspects facilitate the students to understand the conversational competence through the use of movies.

Movies depict how porters work in a hotel. The students recognized the duties of a porter which include carrying guests' luggage, telling directions, explaining hotel facilities, picking up dry cleaning, and taking messages. Movies also represent real-life situation and employ real-life language. Movies facilitate the students to learn how native speakers talk or speak especially in the context of their future job as a porter. The real-life language includes accurate vocabulary, grammar, pronunciation, and content or message used by a porter who works in a hotel. Movies also help the students with multimodal aspects such as gesture, facial expression, voice tone, and others.

Movies facilitate the students to understand social and cultural contexts. Wilson (1994) states that cultural knowledge is essential for communicative competence since language is not only linguistic encoding or decoding but it is grounded in a set of background assumptions together with implicit and explicit norms of cultural behaviors. In this study, the cultural context refers to the way of a porter in asking for tips.

\section{CONCLUSION}

Movies are very useful to teach conversational competence to the students in a vocational high school. The use of movies improves the students' motivation to learn English and increases the students' interest in English. It also makes the teaching and learning of English enjoyable resulting in the increase of the students' active participation in the classroom activities. Movies also facilitate the students to understand verbal and non-verbal conversational competence in the target situation of their future job as a porter. Movies can represent real-life situation and language including its verbal and non-verbal aspects. Movies are really authentic multimedia materials having multimodal aspects to represent real-life situation and language use.

Multimodal aspects help the students to understand conversational competence needed to be a porter as shown in the movies. The multimodal aspects of non-verbal behaviors including intonation and gesture help the students to realize that those are important in conversational competence. The students are able to recognize the multimodal aspects and improve their conversational competence by watching the movies first and practicing in real-life.

Movies are very reccomended to be employed in EFL classes to teach conversational competence, especially for vocational students. Movies will be more powerful when they are utilized with multimodal aspects. It implies that EFL teachers must be capable and well-trained of how to take the advantages of movies and multimodal aspects inside their classrooms. Larger scale researches and other methods of studies are very encouraged to be carried out to discover further about how movies and multimodal aspects play role in EFL classes within different contexts and settings.

\section{REFERENCES}

Alston, M., \& Bowles, W. (2003). Research for social workers: An introduction to methods. Crows Nest, N.S.W: Allen \& Unwin.

Brown, H. D. (2004). Language assessment: Principles and classroom practices. New York: Longman.

Brown, J. (1998). Context creation in discourse understanding. In Malmkjaer, K. \& Williams, J. (Eds.), Context in language learning and language understanding. Cambridge: Cambridge 


\section{University Press.}

Brown, G., \& Yule, G. (1983). Discourse analysis. Cambridge: Cambridge University Press.

Bozorgian, H. (2012). The relationship between listening and other language skills in international language testing system. Theory and Practice in Language Studies, 2(4), 657-663.

Byrne, D. (1986). Teaching oral English. Harlow: Longman.

Celik, O., \& Yavuz, F. (2015). The relationship between speaking grades and listening grades of university level preparatory students. Procedia - Social and Behavioral Sciences, 197, 2137 2140 .

Garrod, S. (1986). Language comprehension in context. Applied Linguistics, 7(3), 226-239.

Goodman, S. (1996). Some elements of English visual grammar. In Goodman, S. \& Graddol, D. (Eds.), Redesigning English: New texts, new identities. London: Routledge.

Jaén, M. M., \& Basanta, C. P. (2009). Developing conversational competence through language awareness and multimodality: The use of DVDs. ReCALL, 21(3), 283-301.

Kramsch, C. \& Anderson, R. W. (1999). Teaching text and context through multimedia. Language Learning and Technology, 2(2), 31-42.

Kirschner, P. A., Sweller, J., \& Clark, R. E. (2006). Why minimal guidance during instruction does not work: An analysis of the failure of constructivist, discovery, problem-based, experiential, and inquiry-based teaching. Educational Psychologist, 41, 75-86.

Kothari, C. R. (2004). Research methodology: Methods and techniques. New Delhi: New Age International $(\mathrm{P})$ Ltd.

Miles, M. B., Huberman, A. M., \& Saldaña, J. (2014). Qualitative data analysis: A methods sourcebook. Los Angeles: Sage.

Oprandy, R. (1994). Listening/speaking in second and foreign language teaching. System, 22(2), 153-157.

Osada, N. (2004). Listening comprehension research: A brief review of the past thirty years. Dialogue, 3, 53-66.

Sukmadinata, N. S. (2012). Metode penelitian pendidikan. Bandung: PT. Remaja Rosdakarya.

Schunk, D. H. (2008). Cognition and instruction. In Schunk, D. H. (Eds.), Learning theories: An education perspective. New York: Pearson.

Wilson, D. (1994). Relevance and understanding. In Brown, G., Malmkjaer, K., Pollit, A., \& Williams, J. (Eds.), Language and understanding. Oxford: Oxford University Press. 